\title{
Ovarian Endometrioid Adenocarcinofibroma
}

National Cancer Institute

\section{Source}

National Cancer Institute. Ovarian Endometrioid Adenocarcinofibroma. NCI Thesaurus.

Code C40060.

A malignant neoplasm of the ovary characterized by the presence of malignant glandular cells resembling endometrial cells in a fibrotic stroma. 